\title{
Erratum: A stroma-related gene signature predicts resistance to neoadjuvant chemotherapy in breast cancer
}

Pierre Farmer, Hervé Bonnefoi, Pascale Anderle, David Cameron, Pratyaksha Wirapati, Véronique Becette, Sylvie André, Martine Piccart, Mario Campone, Etienne Brain, Gaëtan MacGrogan, Thierry Petit, Jacek Jassem, Frédéric Bibeau, Emmanuel Blot, Jan Bogaerts, Michel Aguet, Jonas Bergh, Richard Iggo \& Mauro Delorenzi

Nat. Med. 15, 68-74 (2009); published online 4 January 2009; corrected after print 5 February 2009

In the version of this article initially published, one of the authors' names was misspelled. Pratyakasha Wirapati should have been Pratyaksha Wirapati. The error has been corrected in the HTML and PDF versions of the article.

\section{Erratum: Loss of ETHE1, a mitochondrial dioxygenase, causes fatal sulfide toxicity in ethylmalonic encephalopathy}

Valeria Tiranti, Carlo Viscomi, Tatjana Hildebrandt, Ivano Di Meo, Rossana Mineri, Cecilia Tiveron, Michael D Levitt, Alessandro Prelle, Gigliola Fagiolari, Marco Rimoldi \& Massimo Zeviani

Nat. Med.; doi:10.1038/nm.1907; corrected online 20 January 2009

In the version of this article initially published online, 'SDO' should have been 'SDH' in Figure 4a,b. The error has been corrected for the print, PDF and HTML versions of this article.

\section{Corrigendum: Rescuing a failing heart: putting on the squeeze}

David A Kass

Nat. Med. 15, 24-25 (2009); corrected after print February 52009

In the version of this article initially published, the competing financial interests statement was missing. The error has been corrected in the HTML and PDF versions of the article. 